\title{
OUTLINE CHRONOLOGY OF THE FRENCH MANDATE, 1919-39
}

Year Events

High

Commissioners

(date of appointment)

1917-19 Allied occupation of Arab provinces; end of Georges-Picot First World War; end of Ottoman rule in Arab provinces; Faysali rule in Damascus.

1920 July: Battle of Maysalun; French occupation of Damascus; flight of Faysal.

August-September: formation of Greater Lebanon; state of Aleppo; territory of the 'Alawis; state of Damascus.

To 1921: armed opposition to French rule continues in Alaouites and region of Aleppo. French authority spreads slowly across the mandate territories over the course of the decade.

1922 March: autonomy of Jabal Druze.

June: ‘Syrian Federation' links states of Aleppo and Damascus; state of the 'Alawis (an accidental change of name - and status - for the territory).

July: Mandate over Syria and Lebanon granted to France by League of Nations. 
Year Events

1923

1924 Syrian Federation replaced by state of Syria (unifying states of Aleppo and Damascus); 'Alawi state autonomous.

1925 July: 'Druze Revolt' begins; quickly spreads across southern and central Syria and into Lebanon.

October: bombardment of Damascus.

1926-7 Armed insurgency continues to spring 1927; put down by massive reinforcement of French military presence, with much loss of life.

1928 April: elections to Constituent Assembly in Syria.

Summer: Constituent Assembly meets, draws up constitution that does not acknowledge French presence, is suspended by High Commissioner for six months then sine die.

1930 May: Ponsot permanently dissolves Assembly, promulgates a constitution more acceptable to French.

1931-2 Parliamentary elections (December-January); negotiations between High Commission and Syrian government for Franco-Syrian treaty begin under Ponsot, but unsuccessfully.

1933 Negotiations continue under Martel.

November: draft treaty agreed by Syrian government, text blocked in Parliament. Parliament suspended.

1934 November: Parliament suspended sine die.

1936 Serious unrest in Damascus and other cities in late winter/spring. France agrees to negotiate treaty with Syrian nationalist delegation, which leaves for Paris in March.

\section{High}

Commissioners

Weygand

(19 Apr. 1923)
Sarrail

(2 Jan. 1925)

Jouvenel

(10 Nov. 1925)

Ponsot

(3 Sep. 1926)
Martel

(16 Jul. 1933) 
Year Events

High

Commissioners

(1936 May: Popular Front government in France - a

cont'd) real outcome to negotiations suddenly becomes possible.

September: treaty signed. Return of delegation.

November: legislative elections.

December: Druze and 'Alawi statelets placed under authority of Damascus by decree of High Commission; National Bloc government of Jamil Mardam Bek takes office; Syrian parliament ratifies Franco-Syrian treaty.

1937 July: Franco-Turkish agreement on Sanjak of Alexandretta.

November: Sanjak of Alexandretta becomes independent from Syria as Republic of Hatay. Still under French mandate, its administration begins to adopt Turkish republican norms (law, currency).

1938 December: French government refuses to ratify Puaux Franco-Syrian treaty.

(27 Oct. 1938)

1939 February: fall of Mardam Bek government, triggered by controversy over personal status law reform. Syrian politics at crisis point.

June: formal end of French mandate in Hatay, which becomes a province of Turkish Republic.

July: Druze and 'Alawi regions return to direct French rule; so does the Jazira. Constitution suspended, parliament dissolved.

September: outbreak of Second World War; state of emergency declared in Syria. 